\title{
ABSTRACTS
}

\section{Can Multinational Corporations Help Secure Human Rights and the Rule of Law? The Case of Sudan}

\author{
By Charles Riziki Majinge, London
}

This paper examines the potential role of business entities operating in conflict and post conflict Africa in promoting rule of law and human rights norms. The paper contends that, if at all rule of law and human rights are to be strengthened in resource rich conflict or post conflict areas to enable people to rebuild their societies premised on rule of law ideals, the international community must adopt international binding rules to provide for rights and duties of business entities especially those working in conflict ridden areas like Sudan or DR Congo. Without such binding rules, MNCs operating in conflict afflicted countries will continue taking advantage of corrupt host governments and weak governance system while enjoying the protection of their powerful home governments to continue committing or acquiescing to human rights violations with impunity and in the process inflicting greater harm to the already powerless and impoverished citizens in these countries.

\section{Comparative Observations on the International Reception of the Proportionality Principle}

\section{By Stylianos-Ioannis G. Koutnatzis, Berlin}

Under German law, the limitations of fundamental rights receive constitutional approval only if they pass the three-pronged proportionality test. Accordingly, rights limitations must be suitable, necessary and appropriate vis-à-vis a legitimate governmental purpose. Against this background, this article focuses on the proportionality principle as an example for the reception of German constitutional jurisprudence in transnational constitutional discourse. It provides a comparative overview on the dissemination of the proportionality test in other constitutional systems around the world. The article first outlines the function and applicability of the proportionality principle in German law. It then describes the reception of this principle in Europe and overseas, and compares the proportionality test's fundamental concepts and doctrinal development. While originating in German law, scholars and the courts typically scrutinize limitations of fundamental rights using different versions of proportionality test based on the European Convention on Human Rights, the law of the European Union and the constitutional law of most European states. Further, in countries such as Brazil, South Korea and Japan, German law has inspired the proportionality test analysis, despite considerable differences in its application. In contrast, Canadian jurisprudence has developed a distinct proportionality approach that focuses on the principle of 
minimal impairment of the right or freedom in question. While several common-law jurisdictions, such as Namibia and New Zealand, have followed this approach, others, such as Israel, have ultimately followed the German three-pronged proportionality test. Alternatively, the South African Constitutional Court treats the concepts of proportionality and balancing as virtually interchangeable. Moreover, the article explores the failure of United States courts to explicitly engage in proportionality analysis, and argues that American constitutional doctrine effectively incorporates elements of the proportionality test, albeit employing different terminology. Even legal systems that do not provide for the judicial review of fundamental rights limitations, such as in China or Iran, they in fact incorporate aspects of the proportionality concept. The article identifies a substantial international convergence on the proportionality test as the main criterion to determine the legitimacy of fundamental rights limitations. Yet, the reception models of the proportionality test diverge considerably: For example, in Canada and South Korea, the proportionality test is a means to implement the rule-exception relationship between fundamental rights and their limitations. In contrast, in South Africa, Japan and Brazil, the proportionality test seems to serve merely as the vehicle to allow ad hoc rights balancing. Finally, because the reception of constitutional concepts and doctrines is a mutual process, the article identifies elements from the application of the proportionality principle globally that Europe could follow as well. For instance, European courts may benefit from considering the Canadian and South Korean courts' emphasis on the necessity prong of the proportionality test. In any event, while steering and rationalizing the balancing process, the proportionality test cannot guarantee absolute neutrality in fundamental rights adjudication.

\section{Kenya's New Constitution: a Transforming Document or Less than Meets the Eye?}

\section{By Cornelia Glinz, Heidelberg}

The Kenyans endorsed a new Constitution in a referendum on the $4^{\text {th }}$ of August. This Constitution is claimed to be the most important political development since independence from Great Britain in 1963. The new Constitution is the result of a long-lasting constitutional reform process which was started more than 20 years ago. The initiative for the production of the latest draft was the violence and unrest following the 2007 elections. These dramatic events made the necessity of structural reforms very obvious. The new Constitution can be appraised as a very modern document, particularly through its Bill of Rights which includes a wide array of socio-economic rights. In this respect, it can be seen from the mere content of the text - alongside the South African Constitution - as one of the most progressive documents on the continent and some provisions in the Bill of Rights develop the South African example even further. The transformational potential of the Constitution is also revealed by many other parts. With regard to the new State structure, it is crucial that the power of the President be reduced and likewise democratic legitimacy strengthened, particularly through the empowerment of Parliament. With the topic of land 
reform a sensitive subject was addressed. However, bearing in mind the troublesome political developments over the last few decades in the country there is considerable doubt about whether the political will exists to realise this ambitious text in all aspects. The Article will argue that from a more sceptical perspective it would have been more valuable to concentrate on those issues, especially with respect to the protection of rights, which can realistically be realised and make their judicial enforcement as strong as possible. In the end, the real success of the new Constitution will have to be awaited and will largely depend on how ambitiously the implementation process will proceed in the next few years. This will show whether the Constitution can fulfil the high expectations and serve as the country's turning point towards good governance, democracy, stability and peace.

\section{Traditional Dispute Resolution Mechanisms in Afghanistan and their Relationship to the National Justice Sector}

By Julia Pfeiffer, Heidelberg

Since the collapse of the Taliban regime in Afghanistan, the international community supports the Afghan government in building the rule of law in Afghanistan. The country faces the challenge of legal pluralism and the weakness of state authority in many areas. Hence, the non-state justice institutions still are more popular and reliable for most Afghans than the state justice institutions. The reasons for the bad reputation or rejection are inter alia corruption, long-lasting and expensive proceedings or lack of access to the public sector. Non-state dispute resolution mechanisms on the other hand mainly aim at reconciliation and restoration of peace and harmony within the community in order to maintain stability. They are thus considered fairer and are more accepted by the majority of the population. Non-state justice itself however varies between the different regions of the country, making it difficult to provide a comprehensive overview. The applied rules in the non-state sector are inter alia different customs and traditions of the various Afghan ethnic groups. Nearly every group has its own way to handle disputes, on the basis of own customs.

Since Afghan customs and traditions in some cases violate statutory law, the Shari'a or international human rights standards and the popularity of non-state justice weakens the influence of the state, this issue got more and more into the focus of the actors being involved in the state-building mission conducted in Afghanistan. New attempts for strengthening the rule of law aim at the creation of a linkage between the state and nonstate sectors and at a clearer attribution of competencies between the particular dispute resolution institutions. Therefore, a "Draft National Policy on Relations between the Formal Justice System and Dispute Resolution Councils" has been written, ruling on these topics. The discussion about the policy's implementation into national law is however still ongoing.

The following paper provides a short overview over customs and dispute resolution mechanisms in the Pashtun areas and in Bamyian province. It furthermore discusses the 
relationship between the state and non-state justice sectors in Afghanistan, their historical development and the contemporary situation.

The King of Tonga's constitutional position - from the origins to latest developments

By Dimitrios Parashu, Hannover

The Kingdom of Tonga is reigned by the Tupou-Dynasty since 1845; the State Constitution, established in 1875, arranges a constitutional monarchy theoretically - although to date this system practically was rather more of an absolute monarchy, because of the scale of the King's competences. The present article analyses the status until now as also various efforts of a constitutional reform and the latest changes regarding the position of the monarch.

\section{Transitional Justice and Reconciliation. The Obligations of the International Jurisdiction}

\section{By Philippe Greciano, Paris / Phnom Penh}

Crimes against humanity and war crimes are profound challenges for survivors and state systems. The way back to a peaceful cooperation and sense of justice follows a process of coming to terms with the crimes and the reinforcement of justice. In these instances the international criminal jurisdiction can make a significant contribution, in particular the judgements of the ad hoc tribunals, are very important for history as these courts are equally staffed with local and international personnel in the major functions.

This essay discusses the question to which extent the international jurisdiction, and in particular the ad hoc tribunals, are able to make a contribution to coming to terms with the past and reconciliation in the constitutional state. Particular attention is payed to the development of the ICC and the complex situation in Cambodia. 